\title{
RAD51C wt Allele
}

National Cancer Institute

\section{Source}

National Cancer Institute. RAD51C wt Allele. NCI Thesaurus. Code C51005.

Human RAD51C wild-type allele is located within 17q22-q23 and is approximately $3 \mathrm{~kb}$ in length. This allele, which encodes DNA repair protein RAD51 homolog 3 protein, may play a role in meiotic recombination and repair of damaged DNA. 